\title{
RAZVOJNA PROBLEMATIKA HALOZ NA PRIMERIH KATASTRSKIH OBČIN GORCA IN SLATINA
}

\author{
dr. Vladimir Korošec*, dr. Mirko Pak**, redni prof. v pokoju \\ *Kmetijska srednja šola Ptuj, Wollmerjeva I8, SI-2250 Ptuj \\ *** Pod vrbami I, SI-I000 Ljubljana
}

Izvirni znanstveni članek

COBISS 1.01

\section{Izvleček}

Katastrski občini Gorca in Slatina v Halozah, v eni najmanj razvitih pokrajin SV Slovenije sta primera dolgoletnega zaostajanja $v$ gospodarskem in demografskem razvoju. Neugodne reliefne prilike so v kmetijstvu omogočile le intenzivno vinogradništvo. Zaradi specifičnih lastniških odnosov se je tukaj razvilo viničarstvo, kar je po letu 1945 sprožilo močno depopulacijo, ki je povzročila neugodno socioekonomsko strukturo obeh katastrskih občin in Haloz v celoti.

Ključne besede: Gorca, Slatina, Haloze, Vinorodne Haloze, Slovenija, regionalni razvoj, kmetijstvo, vinogradništvo, turizem, suburbanizacija, deagrarizacija

\section{DEVELOPMENT PROBLEMS OF HALOZE AT THE EXAMPLES OF GORCA AND SLATINA CADASTRAL MUNICIPALITIES}

\begin{abstract}
Gorca and Slatina cadastral municipalities in Haloze, which is one of the least developed regions in the north-eastern Slovenia, are examples of the several-year lagging behind in economic and demographic development. In agriculture, unfavourable relief conditions provided only for intensive wine-growing. Specific proprietorial relationships lead into the development of vineyard-labour relationships which resulted in significant depopulation after 1945 and consequently unfavourable socio-economic structure of both cadastral municipalities and the entire Haloze region.
\end{abstract}

Key words: Gorca, Slatina, Haloze, Wine growing Haloze, Slovenia, regional development, agriculture, wine growing, tourism, suburbanization, deagrarization 


\section{POKRAJINA BREZ PRIHODNOSTI?}

Haloze sodijo med najmanj razvite pokrajine v Sloveniji. Reliefno verjetno najbolj dinamična slovenska pokrajina, zgrajena iz terciarnih peščenjakov, kaže izrazito dvojnost naravnega okolja. Na eni strani bogastvo naravnih vrednot kot pomemben dejavnik trajnostnega razvoja in na drugi strani neugodne posledice zaradi strmega reliefa, nekvalitetnih prsti, erozije, težke prometne prehodnosti, pa tudi obrobnosti in obmejnosti so razlogi gospodarske in socialne nerazvitosti (Korošec 2008, 18). Sedem haloških občin se sooča z ekstremnimi razvojnimi problemi, kljub bližini regionalnega središča Ptuj, okrog 30 km oddaljenega makroregionalnega središča Maribor ter manjših regionalnih središč Slovenske Bistrice, Ormoža in Kidričevega, kamor so se že v petdesetih letih preteklega stoletja pretežno nekvalificirani Haložani vozili na delo in se kasneje tja tudi množično odseljevali. Depopulacija je Haloze tako izpraznila ter preostalo prebivalstvo strukturno tako osiromašila, da je prav to onemogočilo razvojna prizadevanja vse obdobje po drugi svetovni vojni do danes.

Razvojno zaostajanje Haloz v državnem in regijskem okviru se še povečuje. Tako je tudi v obdobju 1981-2007 prebivalstvo po uradnih podatkih nazadovalo za okrog $10 \%$, dejansko pa še za več. Takšno razvojno stanje so potrdili tudi rezultati obeh obsežnih geografskih raziskovalnih projektov o regionalno-razvojni problematiki Spodnjega Podravja leta 1996 in 2010 (Spodnje Podravje 1996; Spodnje Podravje 2010).

Naravni pogoji sicer omogočajo kmetijsko dejavnost, vendar specializacijo s tržno usmeritvijo le v vinogradništvu, saj tudi tradicionalno sadjarstvo že dolga desetletja nima nobenega tržnega deleža. Leta 2010 je bilo 4,7 \% celotnih Haloz in okrog $10 \%$ kmetijskih površin v vinogradih, kar 46,9 \% Haloz pa je pokrival gozd (GURS). Najbolj ploden raziskovalec Haloz, Vladimir Bračič, je Haloze razdelil na vzhodne in zahodne. Prve so nižje in primernejše za gojenje vinske trte, ki pokriva okrog $14 \%$ kmetijskih površin. Višje in strmejše Zahodne Haloze, ki jih imenujejo tudi gozdnate Haloze s samo 2,7 \% kvalitetnih vinogradniških površin, so gospodarsko slabše razviti del regije. Razvojni procesi so v Halozah specifični tudi zato, ker se po denacionalizaciji ponovno kažejo nekateri značilni procesi v lastništvu in rabi zemlje ter v splošni kmetijski 'politiki' in problematiki, značilni za ekstremno nerazvite Haloze pred drugo svetovno vojno. To je še posebej očitno v nižjem vzhodnem in za kmetijstvo ter še posebej za vinogradništvo primernejšem delu Haloz, kjer so se razvili posebni socialnoekonomski odnosi z viničarstvom kot skrajno obliko družbenoekonomske diferenciacije ter $\mathrm{z}$ lastništvom zemlje $\mathrm{v}$ rokah nedomačega in celo tujega prebivalstva.

Vinogradništvo kot vodilna kmetijska in s tem tudi gospodarska dejavnost nazaduje. Za to so bili odločilni nacionalizacija ob koncu druge svetovne vojne, obnova in urejanje obdelovalnih teras $\mathrm{v}$ naravno primernih legah, preoblikovanje Kmetijskega kombinata Ptuj ter denacionalizacija in $\mathrm{s}$ tem povezane spremembe $\mathrm{v}$ rabi tal, zemljiškoposestni strukturi in odnosih. Industrija Maribora, Ptuja in posebno Kidričevega, ki je bilo z okrog 2000 delovnimi mesti, od tega več kot polovico za nekvalificirane delavce, vzrok intenzivne depopulacije Haloz, kjer zato kmetijstvu že desetletja odteguje delovno silo, spreminja prebivalstveno sestavo in odločilno vpliva na nazadovanje in opuščanje vinogradništva. 
$\mathrm{Z}$ denacionalizacijo ter s proizvodnim in poslovnim preoblikovanjem KK Ptuj se je deagrarizacija še poglobila, oboje pa dodatno vpliva na spreminjanje rabe kmetijske zemlje, gospodarsko in prebivalstveno preobrazbo nasploh ter na razvoj pokrajine. Haloze, še posebej vinorodne, imajo s svojim naravnim okoljem in še posebej vinogradništvom znaten turistični potencial. Kot regionalno razvojni dejavnik je turizem izpostavljen v vseh gradivih, vendar znatnejših učinkov v Halozah ni. Turistično najpomembnejši objekti: grad Borl, Gorca in Švabovo so zaprti, prva dva že desetletja. Razmahu vikendaštva v šestdesetih in sedemdesetih letih preteklega stoletja, ki je bilo povezano z vinogradništvom, a že vsaj dvajset zadnjih let nazaduje, sledi skromna urbanizacija. Kakšno korist je regija imela od vikend turizma? Razen tega, da se je ohranilo vinogradništvo na območjih, kjer bi to zaradi parcelne razdrobljenosti že zdavnaj propadlo, da se je v posameznih primerih ohranil tradicionalni stavbni fond, videz kulturne krajine, ter da so se v pokrajini uveljavili elementi urbanizacije.

V času najburnejših deagrarizacijskih procesov v Sloveniji, ko je pospešena industrializacija odtegnila velik del kmečke delovne sile, s tem sprožila silovito deagrarizacijo in dodobra izpraznila tudi Haloze, se je podobno kot drugod po Evropi tudi slovenska geografija lotila poglobljenega preučevanja tovrstne razvojne problematike, ki je slonelo na statistiki in na zelo prepoznavnih sondnih raziskavah katastrskih občin. S sodelovanjem pri raziskavah za potrebe izdelave karte agrarnih sistemov v Evropi, enega največjih mednarodnih geografskih projektov doslej, so se slovenska socialnogeografska preučevanja Oddelka za geografijo Filozofske fakultete v Ljubljani in Inštituta za geografijo tesno povezala z ekonomsko usmerjeno poljsko geografijo in nemško socialno geografijo in pomembno sodelovala pri pripravi splošnih in za slovenske razmere specifičnih teoretskih izhodišč in raziskovalnih metod. To je potem bila osnova tudi za preučevanje Haloz in večjega števila drugih gospodarsko podobno usmerjenih in razvojno bolj ali manj prizadetih slovenskih pokrajin.

Ker so bile Haloze ena od razvojno najbolj problematičnih pokrajin z najbolj izrazitim nedomačim, tudi tujim zemljiškim lastništvom in s tem povezanimi ekstremnimi viničarskimi socialnimi odnosi in problemi v njenem vinorodnem vzhodnem delu, so o tem že pred drugo svetovno vojno pisali sociolog Žgeč in drugi. V šestdesetih letih pa je Bračič $(1967 ; 1982)$ temeljito prečil oba dela Haloz in s tem postavil temelje razumevanju aktualne regionalnorazvojne problematike te specifične slovenske regije. Haloze so bile sredi devetdesetih let prejšnjega stoletja vključene tudi v doslej najobsežnejši slovenski geografski projekt o regionalno razvojni problematiki in v projekt Spodnjega Podravja.

Glede na številne regionalno-razvojne dejavnike, razvojne procese, izredno naravno pestrost, geografski položaj in strukturne značilnosti regije je za podrobnejše razumevanje realnih razvojnih možnosti regije primerna raziskovalna metoda sondna raziskava (case study). V ta namen izbrani katastrski občini sta si v vseh razvojnih elementih diametralno nasprotni. V KO Gorca v občini Podlehnik je bilo še po drugi svetovni vojni več kot 50 \% obdelovalnih površin pretežno v vinogradniških terasah KK Ptuj. Na pretežno strmem površju KO Slatina v občini Cirkulane $\mathrm{z}$ značilno razdrobljeno posestno sestavo in zemljiško zgradbo pa je vinogradništvo izredno nazadovalo, strmine so neobdelane, slemena pa so podvržena urbanizaciji. Posebna pozornost je v raziskavi, ki sloni predvsem na podatkih 
Slika 1: Pregovorno gostoljuben viničar pred svojo kočo v Halozah, pred njo doktorandi Vladimir Bračič, Borut Belec, fotografira Mirko Pak, s svojima mentorjema prof. Svetozarjem Ilešičem in prof. Vladimirjem Klemenčičem, pred skoraj pol stoletja

Figure 1: A proverbially hospitable 'viničar' in front of his cottage in Haloze; in front of the cottage also doctorands Vladimir Bračič, Borut Belec, and Mirko Pak with the camera, and their mentors Prof. Svetozar Ilešič and Prof. Vladimir Klemenčič; almost half a century ago

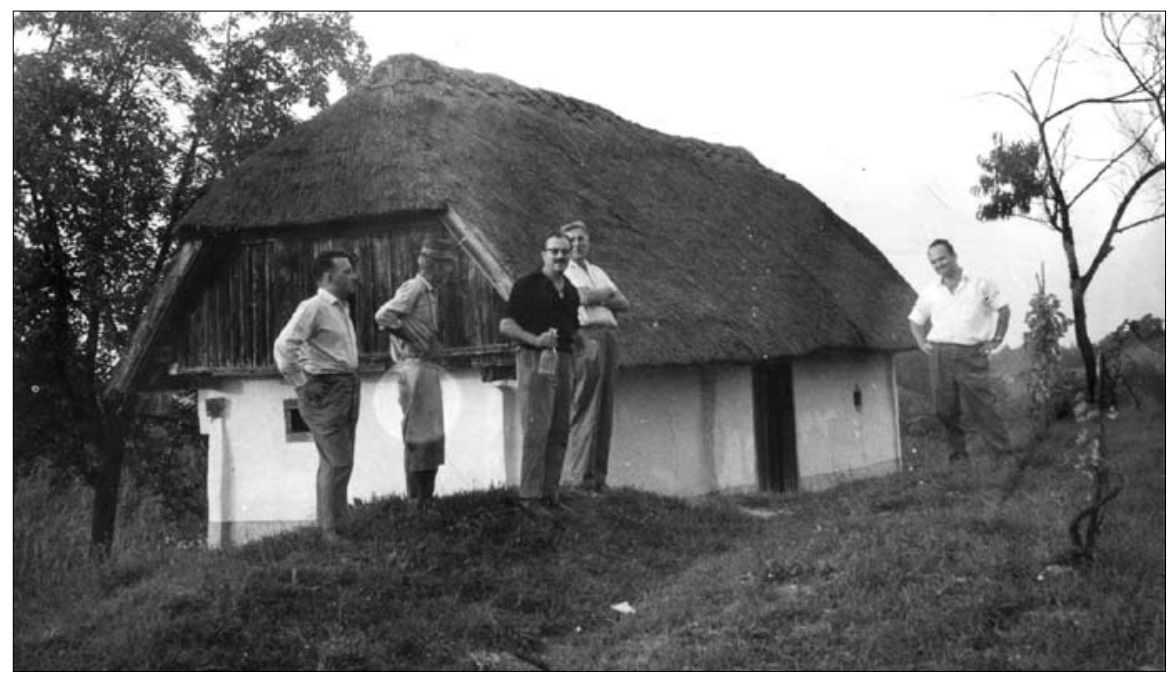

daljšega časovnega obdobja ter na kartiranju in anketiranju, namenjena v Halozah najbolj razširjenim razvojnim procesom.

Spomladi leta 2010 je bilo o problematiki demografske zgradbe, o kmetijski pridelavi in o ekonomski funkciji kmetijstva ter o kakovosti bivanja anketiranih 74 gospodinjstev v KO Gorca in KO Slatina. Na ta način je bilo mogoče opredeliti med seboj silno prepletene in soodvisne razvojne procese, ki so v zadnjih dvajsetih letih oblikovali današnje socialnoekonomsko stanje in nakazati bodoče razvojne možnosti regije v celoti ter še posebej njenega vinorodnega vzhodnega dela.

\section{GEOGRAFSKE ZNAČILNOSTI KATASTRSKIH OBČIN SLATINA IN GORCA}

Na socialnoekonomski razvoj Haloz je vseskozi odločilno vplivala vrsta dejavnikov, od naravnih pogojev, geografskega položaja, odročnosti, obmejnosti in drugih. Naravni pogoji med temi nedvomno izstopajo, kar se kaže tudi v primeru obeh obravnavanih katastrskih občin, ki sicer predstavljata le dve od številnih fizično in razvojno raznolikih in ponekod tudi diametralno nasprotnih pokrajinskih enot. Obravnavani katastrski občini zato zahtevata kratek fizičnogeografski in tudi splošni oris. 
KO Gorca v občini Podlehnik leži med spodnjim tokom Rogatnice in Dravinjo, 15 km zahodno od Ptuja ob magistralni cesti proti Zagrebu. Kopasto uravnano površje na višini 340 do 360 m so vodotoki razrezali v številna krajša slemena v vzporedniški in poldnevniški smeri. Prvovrstne in hkrati najbolj kakovostne vinogradniške lege v Halozah s strmino nad $40^{\circ}$ je v drugi polovici preteklega stoletja Kmetijski kombinat Ptuj preuredil v vinogradniške terase in zasadil nove trajne nasade. Leta 2010 so vinogradi zasedali 53 ha ali 8,8 \% vseh in kar 56 \% obdelovalnih površin 607 ha velike KO Gorca. Površine pod vinogradi so se po letu 1961 zmanjšale za četrtino. Za razliko od drugih območij Haloz pa so se v zadnjih letih površine vinogradov, zaradi sicer redkih primerov celostnih obnov, nekoliko povečale.

Več kot polovico 185 ha velike KO Slatina v občini Cirkulane pokriva gozd. Dve okrog $1,5 \mathrm{~km}$ dolgi in razmeroma ozki slemeni na višini 300 do $320 \mathrm{~m}$ z zelo strmimi pobočji z naklonom 30 do $40^{\circ}$ praktično nista primerni za kmetijsko rabo, vključno z modernim vinogradništvom. Leta 2010 je bilo v Slatini 22 ha vinogradov, kar predstavlja 44 \% obdelovalnih zemljišč. Površina obdelovalnih zemljišč in vinogradov se je v zadnjih letih zmanjšala za tretjino, k čemur je prispevala še velika parcelna razdrobljenost. Vzročno se je po letu 1961 zmanjšalo število prebivalstva.

\section{DEMOGRAFSKI RAZVOJ NE OMOGOČA HITREJŠEGA REGIONALNEGA RAZVOJA}

Demografski razvoj Haloz in demografska zgradba ne napovedujeta hitrejšega splošnega, predvsem pa ne gospodarskega razvoja, ki bi moral vsaj enakovredno temeljiti na lokalnem gospodarstvu, v vzhodnem delu pokrajine na kmetijstvu s težiščem na vinogradništvu. Demografska sestava Haloz, za katero je značilen nizek razvojni potencial z negativnim naravnim prirastkom, staranjem prebivalcev in neugodno izobrazbeno sestavo, je rezultat dosedanjega socialnoekonomskega razvoja ter izrazito omejevalnega vpliva naravnih dejavnikov. »Politične in socialno-ekonomske spremembe sredi preteklega stoletja so ob specifični in močni agrarni prenaseljenosti spodbudile depopulacijo in zaposlovanje v nekmetijskih dejavnostih v industrijskih središčih izven pokrajine. Navedeni procesi niso zgolj pospešili deagrarizacije in preoblikovali gospodarske zgradbe večine naselij, temveč so bistveno spremenili vzorec razpršene poselitve. Ta je izrazito prostorsko diferencirana, opredeljena z obsežnimi območji praznjenja v obmejnih in gričevnatih predelih ter območji zmerne koncentracije v centralnih in dolinskih naseljih« (Korošec 2008, 26). Skoraj polovica prebivalcev Haloz živi v naseljih z izrazito nestabilnim demografskim in gospodarskim razvojem (Korošec 2002, 219). Posledica takšnega demografskega razvoja je naraščajoče pomanjkanje ustrezne kmetijske delovne sile, opuščanje kmetijske pridelave, spreminjanje rabe kmetijskih zemljišč in videza kulturne krajine, kar pomeni popolno socialno, gospodarsko in okoljsko degradacijo gričevnatih in obmejnih območij.

Na podlagi gibanja števila prebivalcev in drugih kazalcev demografskega razvoja uvrščamo naselji Gorca in Slatina med demografsko ogrožena naselja. V drugi polovici preteklega stoletja se je zaradi intenzivnega odseljevanja število prebivalcev v obeh naseljih zmanjšalo skoraj za dve tretjini, v Gorci od 385 v letu 1948 na 155 v letu 2007 in v enakem 
obdobju v Slatini od 279 na 103, kar je hitreje kot v regiji. K temu prispevajo ekonomski, okoljski in socialni dejavniki, slemenska in razpršena poselitev, oddaljenost od zaposlitvenih središč, težji pogoji za kmetijsko pridelavo, dosedanji gospodarski razvoj širšega območja, nepopolna infrastruktura, zemljiška in lastniška razdrobljenost ter drugi.

Analiza ankete in terenskega dela kažeta, da je število prebivalcev v naseljih Gorca in Slatina celo manjše kot navajajo uradni statistični podatki, saj je razmeroma veliko prebivalcev $\mathrm{v}$ haloških naseljih le prijavljenih, medtem ko živijo $\mathrm{v}$ tujini, $\mathrm{v}$ mestih ali v podeželskih naseljih na Dravskem in Ptujskem polju. Na podlagi podatkov anketiranja je mogoče oceniti, da je spomladi leta 2010 v Slatini živelo 82 prebivalcev, torej 21 manj kot jih je bilo stalno prijavljenih, na Gorci pa 141 oziroma 20 manj kot beleži statistika. V obe naselji se je v zadnjem obdobju nekaj prebivalcev tudi priselilo, večinoma v svoje vikende. Kakšnega gospodarsko pomembnejšega demografskega potenciala to starejše priseljeno prebivalstvo ne predstavlja.

Navedene ugotovitve potrjujejo domnevo, da se tudi po letu 2002 število prebivalcev v Halozah zmanjšuje, čeprav kažejo statistični podatki obratno. Vendar je na račun redke poselitve, večjega priseljevanja, motorizacije in s tem izboljšanih pogojev za dnevne migracije, zmanjševanje števila prebivalcev manj intenzivno v primerjavi z najzgodnejšim obdobjem depopulacije med letoma 1948 in 1981.

Preglednica 1: Gibanje števila prebivalcev v obdobju 1981-2010 v Halozah ter v naseljih Slatina in Gorca

Table 1: The population in Haloze hills and Slatina and Gorca villages in the period 1981-2010

\begin{tabular}{|l|c|c|c|c|c|c|}
\hline $\begin{array}{l}\text { Območje, } \\
\text { naselje }\end{array}$ & $\mathbf{1 9 8 1}$ & $\mathbf{1 9 9 1}$ & $\mathbf{2 0 0 2}$ & $\mathbf{2 0 1 0}$ & $\begin{array}{c}\text { Indeks } \\
\mathbf{1 9 8 1 / 2 0 1 0}\end{array}$ & $\begin{array}{c}\text { Indeks } \\
\mathbf{2 0 0 2 / 2 0 1 0}\end{array}$ \\
\hline Haloze & 13.549 & 12.397 & 11.129 & 11.860 & 87,5 & 106,5 \\
\hline Slatina & 150 & 118 & 98 & $82^{*}$ & 59,3 & 83,6 \\
\hline Gorca & 231 & 165 & 148 & $141^{*}$ & 63,2 & 95,3 \\
\hline
\end{tabular}

Viri/Sources: SURS, popisi prebivalstva 1981, 1991 in 2002 ter anketiranje 2002

* Ocena števila prebivalcev na podlagi anketiranja in terenskega dela.

Preglednica 2: Starostna sestava prebivalcev Haloz ter naselij Slatina in Gorca (v\%)

Table 2: Age structure of population in Haloze hills and Slatina and Gorca villages (\%)

\begin{tabular}{|l|c|c|c|c|}
\hline Območje, naselje & Do 14 let & Od 15 do 64 let & Nad 65 let & Starostni indeks \\
\hline Haloze 2007 & 13,2 & 70,7 & 16,1 & 122 \\
\hline Slatina 2007 & 12,6 & 63,1 & 24,3 & 192 \\
\hline Slatina 2010 & 9,1 & 65,2 & 25,8 & 283 \\
\hline Gorca 2007 & 10,3 & 74,9 & 14,8 & 144 \\
\hline Gorca 2010 & 8,3 & 74,2 & 17,4 & 209 \\
\hline
\end{tabular}

Primerjava starostne sestave prebivalcev naselij Slatina in Gorca leta 2007 z rezultati anketiranja v letu 2010 kaže nadaljevanje procesa staranja prebivalcev. Leta 2007 je bilo 
v naselju Slatina v starostni skupini nad 65 let več kot $24 \%$ prebivalcev, v naselju Gorca le okrog $15 \%$, kar je primerljivo z razmerami v Spodnjem Podravju. Nekoliko višji delež prebivalcev v starostni skupini nad 65 let v Slatini v primerjavi z Gorco je posledica zgodnejše depopulacije, ki se je kmalu po drugi svetovni vojni močneje uveljavila v obrobnih haloških naseljih z razdrobljeno zemljiško in posestno zgradbo. V naselju Gorca, kjer je bilo leta 2007 le okrog $10 \%$ prebivalcev mlajših od 14 let, se bo v naslednjem desetletju tako kot v večini haloških naselij, ki ležijo na slemenih ali v obmejnem območju, nadaljeval hiter proces staranja prebivalcev.

Tudi v izobrazbeni in dejavnosti sestavi prebivalcev obravnavanih naselij se odražajo neugodni demografski in gospodarski procesi. Leta 2002 je bilo v obeh naseljih v starostni skupini nad 15 let skoraj $60 \%$ prebivalcev brez izobrazbe ali z dokončano osnovno šolo. Podobne ugotovitve kažejo tudi rezultati anketiranja v letu 2010, saj je bilo na Gorci brez izobrazbe okrog $40 \%$ prebivalcev, v Slatini pa celo 45 \%. Ugodnejše razmere kažejo podatki o deležu prebivalcev z višjo in visoko izobrazbo v naselju Gorca, kjer je sedež župnišča oziroma samostana. Vendar tudi v tem naselju raven izobrazbe ne dosega regijskega in slovenskega poprečja.

$\mathrm{V}$ obeh izbranih naseljih se $\mathrm{v}$ zadnjem obdobju zmanjšuje povezanost prebivalcev $\mathrm{z}$ gospodarskim in socialnim okoljem. Z zmanjševanjem števila kmečkega prebivalstva in poslabšanjem demografske strukture se spreminja agrarna funkcija podeželskih naselij, vendar se predvsem zmanjšuje obseg kmetijske dejavnosti, ne izboljšujeta pa se gospodarska in socialna zgradba (Ravbar 1996, 180). Slatina in Gorca sta do leta 2000 naselji brez delovnih mest izven kmetijstva in z visokim deležem nekmečkega prebivalstva (Korošec 2002, 166). Danes je v kraju bivanja zaposlenih le 6,4 \% delovno aktivnih prebivalcev Slatine in okrog $10 \%$ delovno aktivnih prebivalcev Gorce. Večina prebivalcev se vsakodnevno vozi na delo v bližnja zaposlitvena središča. Največ delovno aktivnih prebivalcev obeh naselij je zaposlenih na Ptuju (38,4 \%), sledijo jim zaposleni v krajih izven regije $(24,1 \%)$. Skoraj $25 \%$ delovno aktivnih prebivalcev Gorce je zaposlenih v Podlehniku in v bližnjih naseljih, kjer se v zadnjem obdobju tudi zaradi njihovega ugodnega položaja močneje razvijajo obrtne in storitvene dejavnosti.

Pomemben kazalec razvoja podeželskih območij je demografska vitalnost gospodinjstev (funkcijska členitev gospodinjstev po starostnih skupinah), saj predstavlja gospodarsko aktivnost območja (Klemenčič, Lampič, Potočnik 2009, 52). Vsa gospodinjstva naselij Gorca in Slatina so s pomočjo metodologije določanja demografske vitalnosti razvrščena $\mathrm{v}$ šest tipov, in sicer: ostarelo gospodinjstvo (vsi člani gospodinjstva so starejši od 70 let), starejše gospodinjstvo (vsi člani gospodinjstva so stari med 50 in 70 let), gospodinjstvo s starejšo srednjo generacijo (starši z otroki, starejšimi od 35 let ali enočlanska gospodinjstva, katerih član je star med 35 in 50 let), gospodinjstvo s srednjo generacijo (otroci so stari od 25 do 35 let ali enočlansko gospodinjstvo, katerih člani so stari od 25 do 35 let), gospodinjstvo treh generacij (gospodinjstvo sestavljajo tri generacije - stari starši, otroci in vnuki) in gospodinjstvo s srednjo in mlado generacijo (predstavljajo ga starši in otroci, ki so mlajši od 25 let). Posebnost demografske zgradbe haloških naselij, ki ležijo na slemenih ali v obmejnem območju, je visok delež eno- ali dvočlanskih gospodinjstev, ki so uvrščena v skupino demografsko ogroženih gospodinjstev. V obeh naseljih je bilo po podatkih anketiranja v letu 
2010 več kot 46 \% eno- in dvočlanskih gospodinjstev, v Slatini celo 50 \%. To vsekakor pomeni nadaljnje zmanjševanje števila prebivalcev in delovnega potenciala obeh naselij.

Slika 2: Perspektivnost gospodinjstev v naseljih Slatina in Gorca leta 2010

Figure 2: Perspectiveness of households in Slatina and Gorca villages, 2010

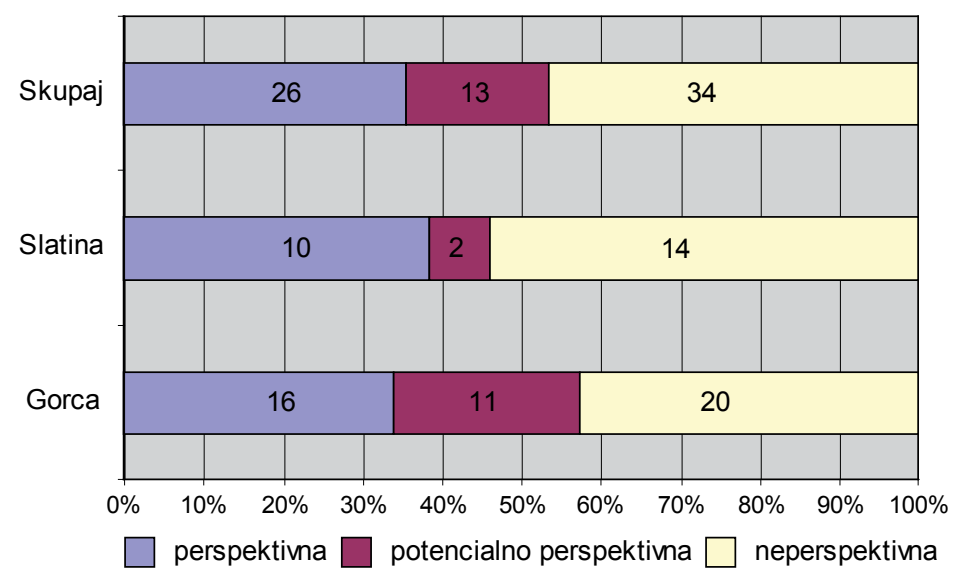

Vir/Source: anketa 2010

V skupino demografsko perspektivnih gospodinjstev so uvrščena gospodinjstva s srednjo in mlado generacijo ter gospodinjstva treh generacij. Takšnih gospodinjstev je bilo v obeh naseljih le dobrih $35 \%$, na Gorci $34 \%$ in v Slatini 38,5 \%, kar ne napoveduje hitrega izboljšanja demografske zgradbe na širšem območju. V skupini demografsko potencialno perspektivnih gospodinjstev so gospodinjstva s srednjo generacijo, ki predstavljajo 17,8 \% vseh gospodinjstev. Več kot $46 \%$ gospodinjstev je demografsko neperspektivnih, kamor uvrščamo ostarela in starejša gospodinjstva ter gospodinjstva s starejšo srednjo generacijo. V Slatini je takšnih gospodinjstev celo 54,8 \%. V večini primerov gre za gospodinjstva, katerih člani so starejši od 50 let, gospodinjstva z enim ali dvema članoma ter gospodinjstva, ki nimajo naslednikov.

Po letu 1991 razvoj prebivalcev na območju Haloz dodatno obremenjuje nova državna meja. Težave so se po sprejemu schengenskega režima na meji še okrepile. Pričakovane oblike čezmejnega gospodarskega sodelovanja (Klemenčič 1996, 211) se niso uveljavile, prav tako se izredno počasi razvijajo storitvene in turistične dejavnosti ob cesti Maribor-Zagreb oziroma v celotnih Halozah.

Izboljšanje demografske zgradbe in ohranjanje poseljenosti je odvisno od lokalnih gospodarskih aktivnosti v kmetijstvu, turizmu in obrti. Govorimo o soodvisnih procesih razvoja prebivalcev na eni strani in razvoja kmetijstva, turizma, obrti in drugih dejavnosti, ki temeljijo na lokalnih virih na drugi strani. V demografsko degradiranem okolju je gospodarska revitalizacija dolgotrajen, zahteven in izjemno kompleksen proces, ki mora biti sestavni del regionalne razvojne politike. 


\section{HALOŠKO KMETIJSTVO JE ODVISNO OD ŠTEVILNIH DEJAVNIKOV}

Razvoj haloškega kmetijstva je v drugi polovici preteklega stoletja zaznamovala depopulacija, ki je povzročila pomanjkanje delovne sile v kmetijstvu, spreminjanje rabe in zaraščanje zemljišč ter delitev zemlje in spremembe lastništva. Zaradi tega najbolj vidno nazaduje vinogradništvo, saj v zadnjem desetletju ni bilo pomembnejših obnov, ni proizvodnih in tehnoloških novosti v kmetijski pridelavi, ni poslovnega in strokovnega povezovanja med kmetovalci ter med kmetovalci in gospodarskimi subjekti.

Velikostna in posestna razdrobljenost sta rezultat naravnih pogojev ter zapletenih historičnih, socialnih in ekonomskih procesov. Po podatkih GURS je bila v Halozah v letu 2010 poprečna velikost parcelnih delov 0,32 ha, kar je zaradi višjega deleža gozda, ki zavzema okrog 47 \% vseh površin, nekoliko nad poprečjem severovzhodne Slovenije in Spodnjega Podravja. $\mathrm{V}$ primerjavi z ostalimi območji v regiji je v Halozah velika parcelna razdrobljenost kmetijskih površin: poprečna njivska parcela meri 0,23 ha, sadjarska 0,24 ha, vinogradniška pa le 0,21 ha.

Poleg velikosti in parcelne razdrobljenosti je za Haloze značilna lastniška razdrobljenost, saj je veliko kmetijskih zemljišč v lasti odseljenih domačinov, ki so se v drugi polovici preteklega stoletja izselili v industrijska središča, lastnikov vikendov ter domačih in tudi tujih vinogradnikov. Vse do druge svetovne vojne je bila večina največjih in najlepših vinogradov v lasti veleposestnikov in vinskih trgovcev. Bračič ugotavlja, da so imeli v vinorodnih Halozah leta 1935 ptujski in graški meščani ter kmetje s Ptujskega in Dravskega polja v lasti 33,6 \% vseh zemljišč in 48,8 \% vseh vinogradov (Bračič 1967, 132-133). Po drugi svetovni vojni so veleposestnike nadomestila državna posestva, hkrati se je močno povečalo število vikend bivališč z majhno vinogradniško pridelavo. V vinorodnih Halozah se je leta $1963 \mathrm{v}$ primerjavi z letom 1935 število posestnikov povečalo za 14 \% (Bračič 1967, 183). V zadnjem obdobju se zaradi denacionalizacije ter opuščanja vinogradniške pridelave lastništvo vinogradov ponovno spreminja. Večina denacionalizacijskih upravičencev, ki so jim v postopkih denacionalizacije vinograde vrnili, se danes ne ukvarja z vinogradništvom, temveč so jih prodali ali oddali v najem. Marsikje so te vinograde ponovno odkupili tujci. Vinogradniško pridelavo opušča tudi vse več vinogradnikov, ki so v 90. letih preteklega stoletja prevzemali vinograde Kmetijskega kombinata Ptuj ter tudi lastniki vikendov.

Depopulacija je močno oslabila prebivalstvene potenciale v kmetijstvu oziroma povzročila demografsko izčrpanost območja (Klemenčič 2005, 177). Za haloške kmetije je značilna nadpovprečna starost lastnikov kmetij in nizka izobrazbena sestava članov kmečkih gospodinjstev. Primerjava podatkov o starostni in izobrazbeni sestavi med vsemi anketiranimi in kmečkimi gospodinjstvi v obeh naseljih kaže nekoliko ugodnejši položaj kmečkih gospodinjstev na Gorci zaradi večje proizvodne in tržne usmerjenosti posameznih kmetij. Leta 2010 je bila povprečna starost lastnikov kmetij v Slatini skoraj 60 let, na Gorci pa 55 let. Izrazito neuravnotežena je starostna sestava članov gospodinjstev, saj v obeh obravnavanih naseljih delež otrok, starih do 14 let ne presega $10 \%$. V Slatini je bilo v starostni skupini nad 65 let 21,9 \% članov kmečkih gospodinjstev. Izobrazbena sestava, ki je v sodobnih družbah ključna sestavina v razvoj usmerjene družbene skupnosti, ne napoveduje hitrih sprememb 
(Ravbar, Razpotnik 2008, 90). O demografskem potencialu govori podatek, da je samo na treh kmetijah polno zaposlen le po en družinski član in na dveh kmetijah po dva. Na vseh ostalih več kot $80 \%$ kmetijah člani gospodinjstva kmetujejo ob redni zaposlitvi oziroma so upokojeni. Na kmetijah vinorodnih Haloz ni presežkov delovne sile, kar ugotavlja tudi Kladnik in opozarja na propadanje kulturne krajine zaradi zmanjševanja kmetijske dejavnosti (Kladnik 1996, 308).

\section{SPREMINJANJE RABE ZEMLJIŠČ V OBDOBJU I96I-20I0}

V rabi tal se odražajo kompleksni odnosi med naravnimi in družbenimi dejavniki v pokrajini (Klemenčič, Lampič, Potočnik 2009, 34). Na spreminjanje rabe kmetijskih zemljišč v Halozah poleg naravnih dejavnikov in zemljiške razdrobljenosti vplivajo demografske in gospodarske razmere $v$ regiji in državi; še posebej izstopajo staranje prebivalcev, pomanjkanje znanja, inovativnosti in podjetniške usmerjenosti med kmetovalci, nepovezanost pridelovalcev, neurejenost in nestabilnost kmetijskega trga in mnoge druge. Posledice spreminjanja rabe se kažejo $\mathrm{v}$ preoblikovanju kulturne krajine ter $\mathrm{v}$ poselitvi. $\mathrm{V}$ večjem delu Haloz se kot prevladujoča tipa sprememb uveljavljata ozelenjevanje in ogozdovanje, kar povečuje ekološko ranljivost okolja, zmanjšuje biotsko pestrost ter dolgoročno ogroža uveljavljanje različnih oblik turizma in rekreacije ${ }^{1}$.

Slika 3: Raba zemljišč v Halozah v deležih v letih 1963, 1997 in 2010

Figure 3: Land use in Haloze hills in the years 1963, 1997, 2010 (\%)

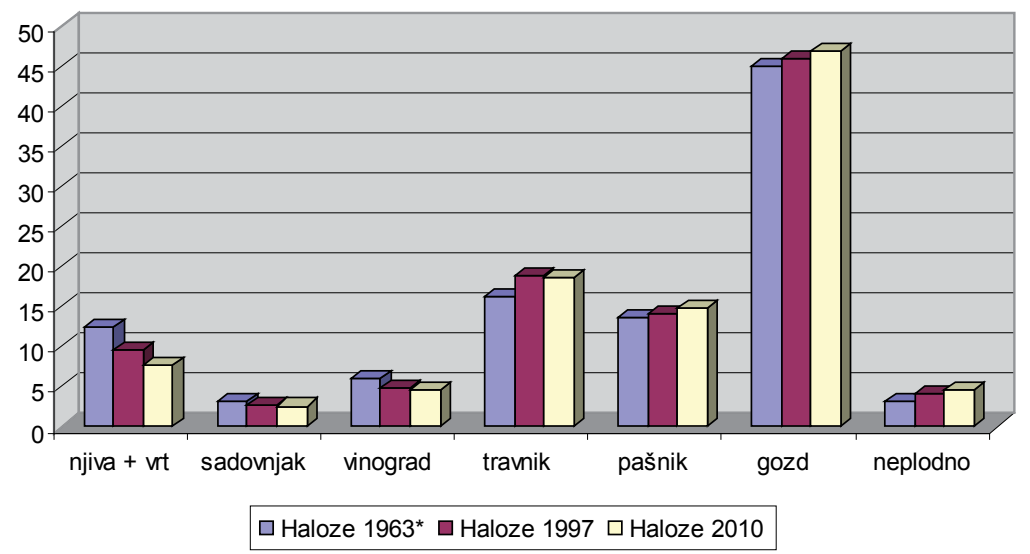

Vir/Source: Bračič 1967, GURS

*Podatki so povzeti po Bračiču, prirejeni na podlagi katastrskih elaboratov za leti 1963 in 1978

\footnotetext{
${ }^{1} \mathrm{~V}$ prispevku je spreminjanje rabe tal prikazano na dveh ravneh. Prvo raven predstavljajo spremembe rabe na celotnem območju Haloz od druge polovice preteklega stoletja do danes. Analiza je bila izdelana na podlagi literature in podatkov GURS. Druga raven preučevanja obsega podrobno analizo spreminjanja rabe kmetijskih zemljišč v katastrskih občinah Gorca in Slatina. V ospredju preučevanja je spreminjanje obsega vinogradniških površin v letih 1961, 1994 in 2010. Analize in karte so izdelane na podlagi statističnih podatkov, terenskega dela in ortofoto posnetkov.
} 
Spreminjanje rabe kmetijskih zemljišč na območju Haloz je v prvi vrsti posledica depopulacije. Ozelenjevanje in ogozdovanje je najmočnejše v slemenskih, gričevnatih in obmejnih predelih, od koder se je v drugi polovici preteklega stoletja odseljevalo največ prebivalcev. Po letu 1963 se je v Halozah za 1194 ha zmanjšala površina njiv in za 357 ha vinogradov. Na drugi strani so se povečale površine travnikov, neplodnih zemljišč in gozdov, ki prekriva kar 47 \% Haloz. V povezavi s spreminjanjem rabe tal se je preoblikovala gospodarska zgradba večine naselij, v katerih se zmanjšujeta delež kmečkih gospodinjstev in tržna usmerjenost kmetijstva. Kljub povečanju travniških in pašnih površin, ki obsegajo tretjino vseh zemljišč, je govedoreja nazadovala. V zadnjem obdobju se uveljavlja reja drobnice, ki pa ne daje pomembnejših gospodarskih rezultatov.

Tako v Slatini kot na Gorci je bil gozd že sredi preteklega stoletja prevladujoča kategorija rabe prostora. Medtem ko so bile v Slatini leta 1961 na drugem mestu njive, ki so zavzemale 21,6 \% vseh zemljišč in na tretjem mestu vinogradniške površine, so bili na Gorci travniki in pašniki druga oziroma tretja najpogostejša oblika rabe. Po podatkih za leto 2010 se je v Slatini delež njiv zmanjšal na 10,9 \% skupnih površin. Opuščene njive in vinograde so pretežno prerasli travniki in pašniki, medtem ko so se v katastrski občini Gorca ob občutnem zmanjšanju njiv povečale predvsem gozdne površine. V obeh katastrskih občinah so se po letu 1961 vinogradniške površine zmanjšale skoraj za tretjino (slika 5). Na Gorci, kjer prevladujejo obsežni strnjeni vinogradniški kompleksi, se je v zadnjem obdobju nekoliko upočasnil proces zaraščanja. Po denacionalizaciji se od sredine 90. let preteklega stoletja spreminja tudi lastništvo vinogradov. Največ lastniških sprememb je na Gorci, kjer so obsežne strnjene vinogradniške površine k nakupu pritegnile tuje vinogradnike. Slednji poleg obnove vinogradov

Slika 4: Za Slatino je značilna razpršena poselitev in zaraščanje vinogradov

Figure 4: Slatina is characterised by dispersed settlement and owergrowing of vineyards

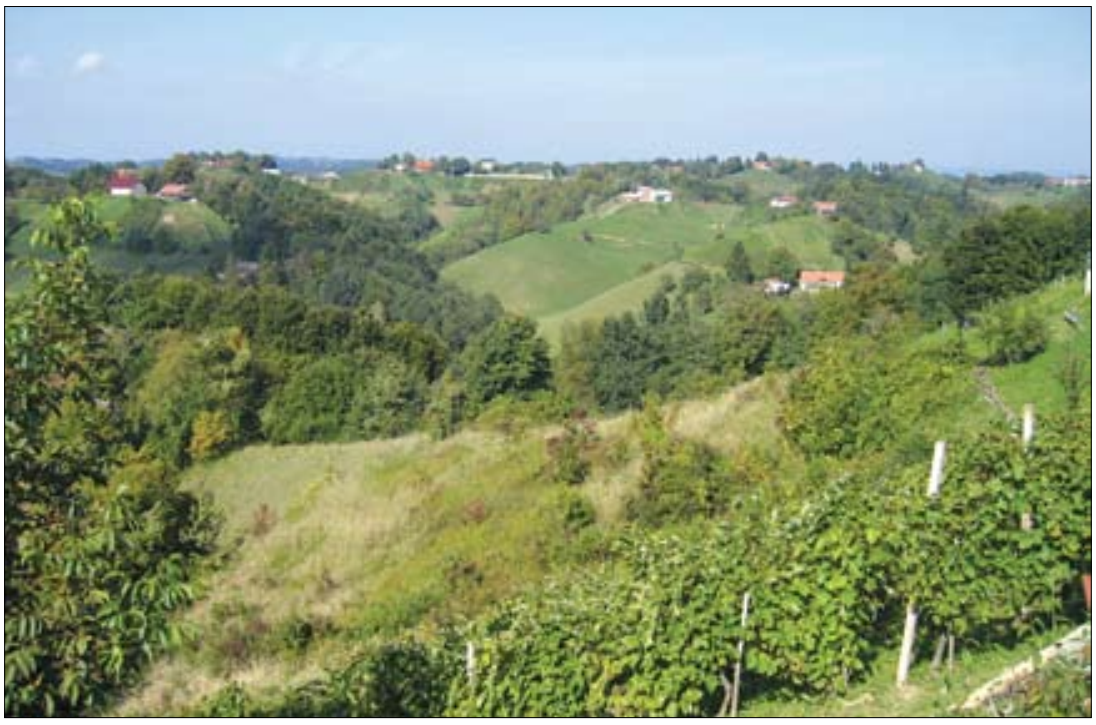


Slika 5: Spreminjanje vinogradniških površin v KO Slatina in KO Gorca

Figure 5: Transformation of wine growing areas in the Slatina and Gorca cadastral municipalities

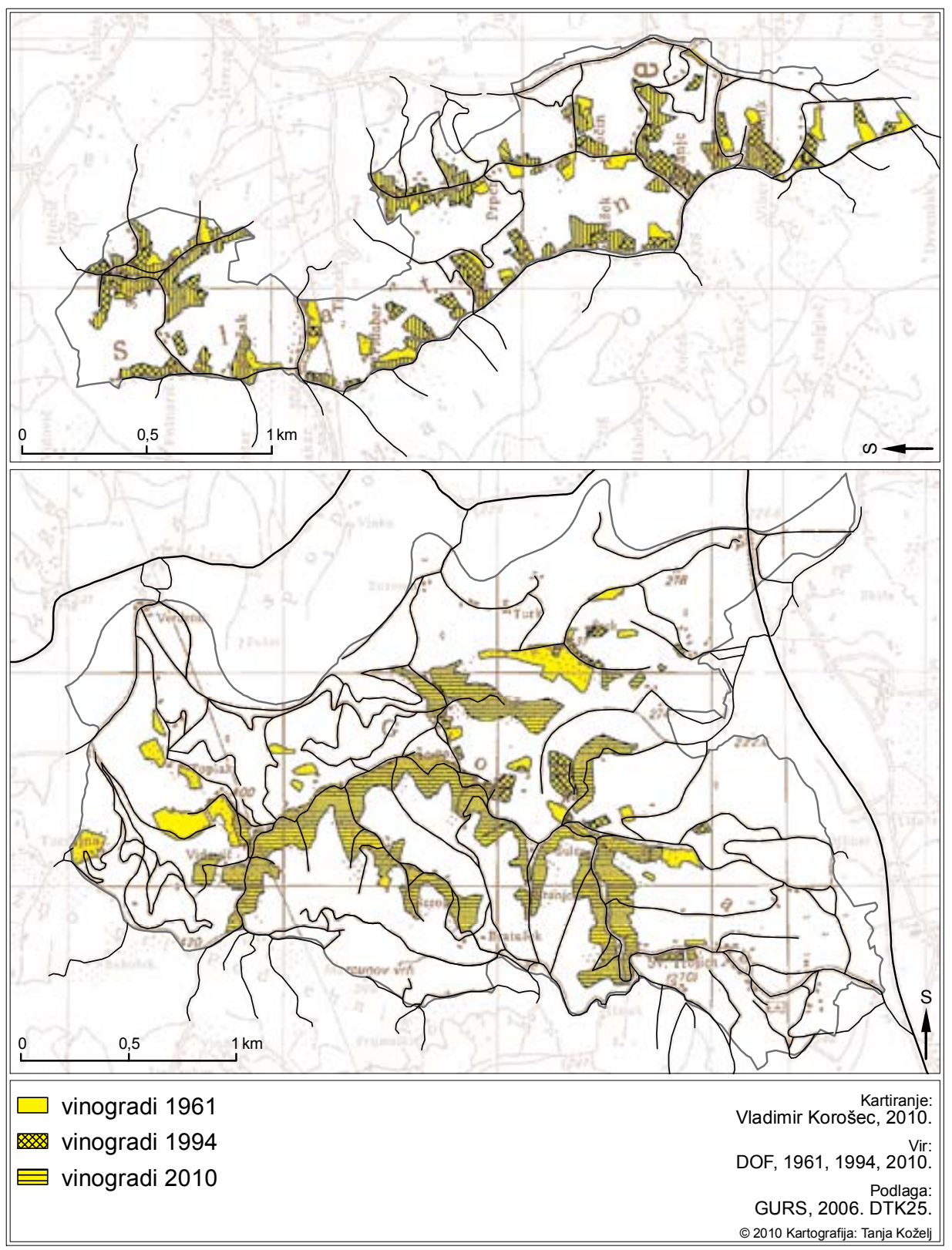


Slika 6: Namembnost stavb v KO Slatina in KO Gorca

Figure 6: Intended use of buildings in the Slatina and Gorca cadastral municipalities

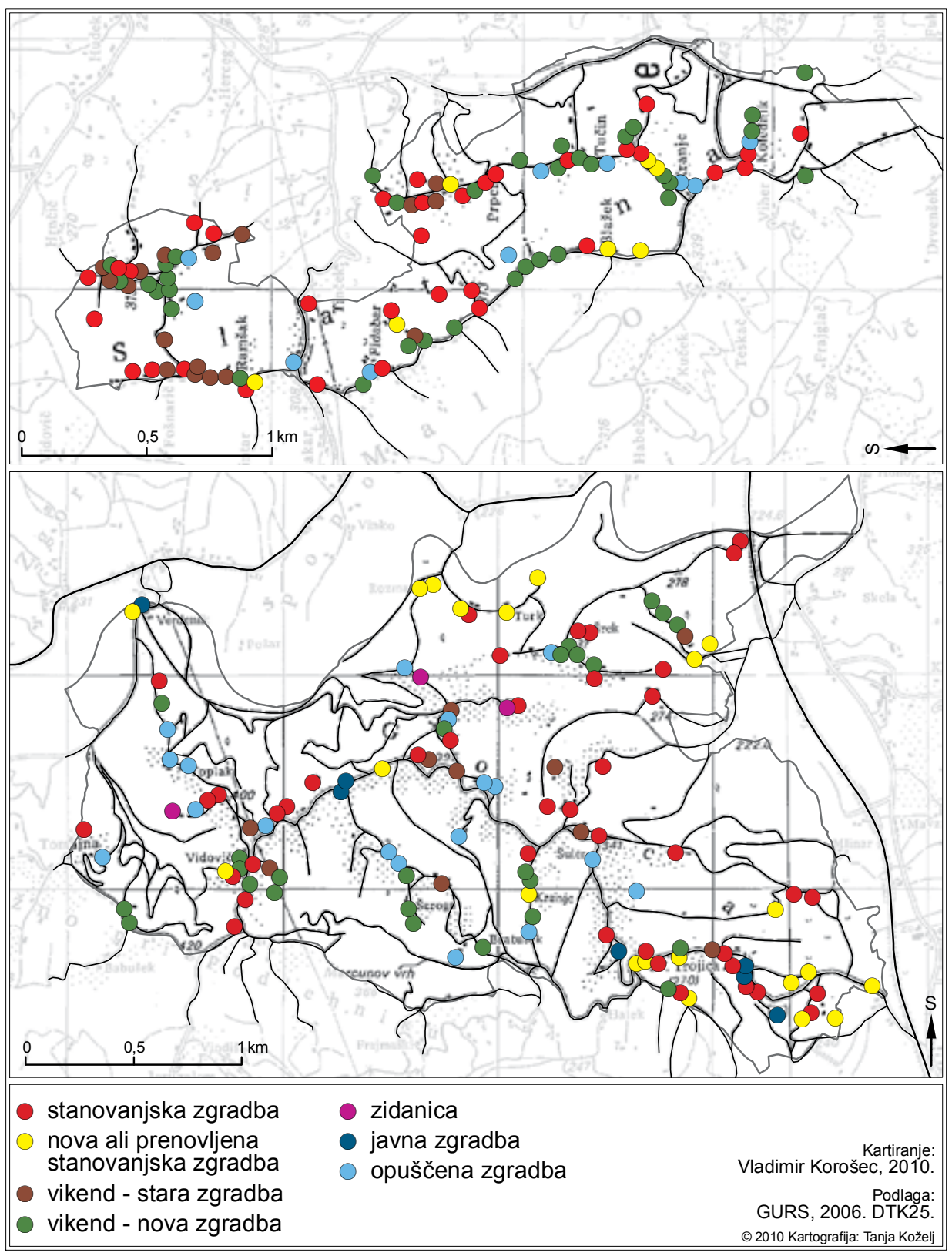


načrtujejo izgradnjo vinske kleti, kar je lahko dobra spodbuda za razvoj ali ohranjanje vinogradništva v tem delu Haloz ter za vzpostavljanje novih oblik sodelovanja.

Opuščanje kmetijstva je posledica socialnih in ekonomskih sprememb v podeželskih naseljih ter naravnih dejavnikov. Na opuščanje kmetijske obdelave v Halozah vpliva tudi izboljšanje življenjskega standarda, saj mnoga gospodinjstva z zaposlitvijo v nekmetijskih dejavnostih pridobijo dovolj dohodka za preživetje.

V Slatini se bo nadaljevalo opuščanje obdelovalnih površin oziroma spreminjanje njiv in vinogradov $\mathrm{v}$ travnike in pašnike, za katere kmetovalci lahko še vedno uveljavljajo nadomestila za območja z omejenimi dejavniki. Ocenjuje se, da je v zadnjem obdobju zaraščanju izpostavljenih 5 do $10 \%$ zemljišč, ki pretežno ležijo na strmih pobočjih ali v ozkih grapah, zaradi česar se vidno spreminja videz kulturne pokrajine.

V Slatini preseneča razmeroma velik obseg opuščenih vinogradov, kar je posledica neugodnih tržnih razmer na področju vinogradništva oz. zniževanja odkupnih cen grozdja (slika 6). Vinogradniki, ki so vpisani v register pridelovalcev grozdja, opuščajo vinogradniške površine na podlagi ukrepa ministrstva za kmetijstvo ter uveljavijo nadomestilo za krčenje vinogradov. Opuščanje vinogradniških površin kaže na številne organizacijske probleme v vinogradniški dejavnosti, predvsem na nepovezanost pridelovalcev grozdja, ki doslej niso razvili skupne predelave in ne enotne blagovne znamke za haloška vina. Opuščajo se tudi vinogradi ob vikendih, saj mlajša generacija lastnikov ne kaže zanimanja za to dejavnost in za tovrstno preživljanje prostega časa.

Preglednica 3: Raba zemljišč po posameznih kategorijah v \% v letih 1961, 1997 in 2010

Table 3: Land use by land categories in the years 1961, 1997, 2010 (\%)

\begin{tabular}{|l|c|c|c|c|c|c|c|}
\hline $\begin{array}{l}\text { Naselje, } \\
\text { območje }\end{array}$ & $\begin{array}{c}\text { Njiva, } \\
\text { vrt }\end{array}$ & Sadovnjak & Vinograd & Travnik & Pašnik & Neplodno & Gozd \\
\hline Slatina 1961 & 21,6 & 5,4 & 16,2 & 13,5 & 14,3 & 2,7 & 26,3 \\
\hline Slatina 1997 & 11,9 & 4,8 & 12,8 & 17,9 & 21,6 & 3,6 & 27,4 \\
\hline Slatina 2010 & 10,4 & 4,7 & 11,7 & 18,4 & 22,5 & 3,9 & 28,4 \\
\hline Gorca 1961 & 9,1 & 2,3 & 11,7 & 18,8 & 12,7 & 4,1 & 41,3 \\
\hline Gorca 1997 & 4,6 & 2,4 & 8,5 & 25,1 & 6,4 & 4,7 & 48,3 \\
\hline Gorca 2010 & 4,4 & 2,4 & 8,8 & 24,9 & 6,5 & 4,7 & 48,3 \\
\hline Haloze* 1963 & 12,5 & 3,1 & 6,1 & 16,3 & 13,7 & 3,3 & 45,0 \\
\hline Haloze 1997 & 9,6 & 2,7 & 4,8 & 18,8 & 14 & 4,2 & 45,9 \\
\hline Haloze 2010 & 7,8 & 2,6 & 4,7 & 18,7 & 14,7 & 4,6 & 46,9 \\
\hline
\end{tabular}

Vir/Source: GURS, ZA Ptuj

* Glej opombo pod sliko 3

V katastrski občini Gorca je večina njiv na terasah in na aluvialni naplavini ob Rogatnici in Dravinji, zato ni pričakovati njihovega zmanjševanja. V prihodnosti se tudi ne bo bistveno zmanjšal obseg vinogradov, ki oblikujejo strnjene komplekse intenzivne rabe, hitro pa 
se zmanjšujejo travne površine, ki jih prerašča gozd. Na Gorci se postopno oblikujeta dve prevladujoči kategoriji rabe zemljišč: na eni strani je gozd, ki zavzema skoraj polovico vseh površin in se bo v prihodnje še širil, drugo pomembno obliko rabe pa predstavljajo vinogradniške površine, ki se sicer ne povečujejo, a narašča njihov delež v odnosu do obdelovalnih površin.

\section{HALOZE BI LAHKO BILE EVROPSKI PRIMER VINOGRADNIŠKE IN BIVALNE REGIJE}

Haloze se od druge polovice preteklega stoletja oklepajo tradicionalnega kmetijstva ter ohranjajo gospodarsko monostrukturo agrarne dobe, kar povzroča siromašenje regionalnih struktur (Klemenčič 2003, 162). Med pomembnejšimi proizvodnimi ukrepi so bile le obsežne obnove vinogradov, ki jih je na najbolj kakovostnih legah v drugi polovici preteklega stoletja izvajal Kmetijski kombinat Ptuj, medtem ko se večje privatni vinogradniki uveljavijo šele po letu 1991. V primerjavi z drugimi območji Spodnjega Podravja se je v Halozah počasneje manjšal delež gospodinjstev s kmečkim gospodarstvom. Zaradi socialnih razmer prebivalci ohranjajo stik s kmetijskimi zemljišči, na katerih pridelujejo v glavnem za lastne potrebe. V Slatini ima skoraj polovica vseh gospodinjstev kmetijsko gospodarstvo (anketa 2010). Velikost kmetij se v zadnjih desetih letih ni bistveno spremenila (Korošec 2005, 38). V Slatini kot značilnem naselju malih kmetov se je zaradi opuščanja pridelave celo povečal delež kmetij z manj kot 1 ha zemlje. Zaradi opuščanja pridelave na majhnih kmetijah se ne spreminja velikostna sestava kmetij. Ker majhne in razdrobljene parcele za tržno pridelavo niso zanimive, ostajajo opuščene parcele $\mathrm{v}$ glavnem neobdelane, $\mathrm{k}$ čemur prispevata pomanjkanje delovne sile, ki je zaposlena izven kmetijstva, ter neugodni naravni pogoji kot so ekstremna strmina, slabe prsti in drugo.

Preglednica 4: Gospodinjstva s kmetijskim gospodarstvom v letih 2000 in 2010

Table 4: Households on farms in the years 2000 and 2010

\begin{tabular}{|l|c|c|c|c|c|c|}
\hline \multirow{2}{*}{ Naselje } & \multicolumn{3}{|c|}{ Leto 2000 } & \multicolumn{2}{c|}{ Leto 2010 (ocena na osnovi ankete) } \\
\cline { 2 - 7 } & $\begin{array}{c}\text { Število } \\
\text { gospodinjstev }\end{array}$ & $\begin{array}{c}\text { Kmečka } \\
\text { gospodinjstva }\end{array}$ & $\begin{array}{c}\text { Delež } \\
\text { \% }\end{array}$ & $\begin{array}{c}\text { Število } \\
\text { gospodinjstev }\end{array}$ & $\begin{array}{c}\text { Kmečka } \\
\text { gospodinjstva }\end{array}$ & $\begin{array}{c}\text { Delež } \\
\%\end{array}$ \\
\hline Slatina & 36 & 19 & 52,8 & 26 & 12 & 46,2 \\
\hline Gorca & 51 & 16 & 31,4 & 47 & 14 & 29,8 \\
\hline Skupaj & $\mathbf{8 7}$ & $\mathbf{3 5}$ & $\mathbf{4 0 , 2}$ & $\mathbf{7 3}$ & $\mathbf{2 6}$ & $\mathbf{3 5 , 6}$ \\
\hline
\end{tabular}

Vira/Sources: Popis prebivalstva 2000 in anketiranje 2010

V Halozah se zmanjšuje tržna usmerjenost kmetij in njihova ekonomska učinkovitost. Socialnoekonomska sestava kmetij v obeh naseljih kaže, da večina kmetij pridobiva večji del dohodka izven kmetijstva. Od 26 kmetij je le ena čista, 6 je mešanih in 19 dopolnilnih $(73,1 \%)$. Tri kmetije občasno prodajajo tržne viške in le štiri so tržno usmerjene in specializirane. Prevladujejo vinogradniške kmetije in le na eni kmetiji se ukvarjajo z rejo drobnice v povezavi z dopolnilno dejavnostjo. Dopolnilno delo so uveljavile tri kmetije, ki se ukvarjajo 
s predelavo mleka, peko kruha in peciva ter s turistično dejavnostjo, kar nakazuje nove poti pridobivanja dohodka v okolju z dokaj skromno kmetijsko pridelavo. Razvoj dopolnilnih dejavnosti je odvisen od znanja, inovativnosti in finančnih virov na kmetiji, predvsem pa od proizvodne, tehnološke in ekonomske stabilnosti osnovne kmetijske dejavnosti (Potočnik 2002 , 111). Nedvomno je to tudi eden od razlogov za počasno uveljavljanje dopolnilnih dejavnosti na haloških kmetijah.

Preglednica 5: Velikostna sestava kmetij v letih 2000 in 2010 v deležih

Table 5: The size structure of farms in the years 2000 and 2010 (\%)

\begin{tabular}{|l|c|c|c|c|c|c|c|c|}
\hline \multirow{2}{*}{ Naselje } & \multicolumn{4}{|c|}{ Leto $\mathbf{2 0 0 0}$} & \multicolumn{3}{c|}{ Leto 2010 (ocena na osnovi ankete) } \\
\cline { 2 - 10 } & do $\mathbf{1}$ ha & $\mathbf{1}-\mathbf{5}$ ha & $\mathbf{5}-\mathbf{1 0}$ ha & nad $\mathbf{1 0}$ ha & do $\mathbf{1}$ ha & $\mathbf{1}-\mathbf{5}$ ha & $\mathbf{5}-\mathbf{1 0}$ ha & nad $\mathbf{1 0}$ ha \\
\hline Slatina & 15,8 & 73,7 & 10,5 & $/$ & 41,7 & 33,3 & 25 & \\
\hline Gorca & 12,5 & 56,3 & 25,0 & 6,2 & 14,3 & 50,0 & 28,6 & 7,1 \\
\hline Skupaj & $\mathbf{1 4 , 3}$ & $\mathbf{6 5 , 7}$ & $\mathbf{1 7 , 1}$ & $\mathbf{2 , 9}$ & $\mathbf{2 6 , 9}$ & $\mathbf{4 3 , 3}$ & $\mathbf{2 6 , 9}$ & $\mathbf{2 , 9}$ \\
\hline
\end{tabular}

Vira/Sources: Popis prebivalstva 2000 in anketiranje 2010

S predelavo grozdja se ukvarjata le dve tržno usmerjeni vinogradniški kmetiji na Gorci, medtem ko ostale kmetije prodajajo grozdje različnim kupcem ali po pogodbi v ptujsko klet. O preostalem kmetijstvu v obravnavanih naseljih govori podatek, da sta po letu 1990 le dve kmetiji povečali površino svojih kmetijskih zemljišč in prav tako sta dve uveljavili specializacijo (anketa 2010). Na sedmih kmetijah (26,9 \%) so opustili del zemljišč in na desetih (38,5 \%) zmanjšali obseg pridelave. Skoraj polovica kmetij ima naslednika, vendar to ni zagotovilo, da se bodo nasledniki ukvarjali s kmetijsko pridelavo. Kmetovalci med razlogi za zmanjšanje ali opuščanje kmetijske pridelave izpostavljajo težje pridelovalne pogoje in slabe razmere v kmetijstvu. Dejstvo je, da prav zahtevni naravni pogoji, velika strmina, težka tla in lega, ki zahtevajo pretežno ročno obdelavo, dajejo haloškim vinom posebno kakovost, kar pa vinogradniki pri promociji svojih vin premalo izkoristijo. Vzhodne Haloze se ponašajo z dolgo vinogradniško in kletarsko tradicijo, primanjkuje pa izkušenj na področju promocije in prodaje.

Demografski in gospodarski razvoj Haloz je nedvomno povezan s kmetijstvom, ki je temeljni vzdrževalec podeželske pokrajine v sodobni družbi (Klemenčič, Lampič, Potočnik 2009, 9). Mnenja o tem, katere kmetijske dejavnosti bi morali v Halozah spodbujati in razvijati, so zelo različna. Skoraj v enakem deležu so anketirani prebivalci naselij Gorca in Slatina razvrstili naslednje odgovore: razvoj različnih kmetijskih panog in dopolnilnih dejavnosti, specializirana pridelava (vinogradništvo), turizem na kmetijah in ekološko kmetijstvo. Z ustreznim pristopom lahko postopno zagotovimo razvoj vseh navedenih kmetijskih dejavnosti. Sočasno s kmetijstvom je potrebno krepiti tudi pogoje za razvoj storitvenih dejavnosti, obrti in podjetništva, kar bo pritegnilo mlade in prebivalce $\mathrm{z}$ višjo stopnjo izobrazbe. Regionalni razvojni programi ter Program razvoja podeželja v obdobju 2007-2013 po vzoru zahodnih držav uvajajo racionalne načine reševanja družbenih problemov z vključevanjem pobud civilne družbe in različnimi oblikami partnerstev s privatnim sektorjem (Klemenčič, 2005, 192), kar v Halozah zaradi različnih vzrokov ni zaživelo. Haloze se lahko učinkovito razvijajo 
z uveljavljanjem lokalnih gospodarskih iniciativ ter krepitvijo regionalnih poslovnih povezav.

\section{SPREMINJANJE POSELITVENE ZGRADBE}

V Halozah prevladuje dvojna poselitev, slemenska in dolinska, kar velja tudi za obe obravnavani katastrski občini. Prvotna, s kmetijstvom funkcionalno povezana poselitev, je pritegnila tudi novejšo in v zadnjem dobrem desetletju najnovejšo suburbanizacijo. Tradicionalna slemenska poselitev stanovanjskih hiš in vikendov je tudi pejsažno vedno bolj dominantna. Manj novogradenj je v dolinah, z izjemo lokalnih središč, medtem ko je za redka pobočna poslopja, največkrat prometno odročne nekdanje viničarije, najmanj zanimanja. Tako so tudi v Gorci in v Slatini slemensko poselitev najbolj zgostile hiše domačega prebivalstva, potomcev nekdanjih viničarjev, vračanje odseljenih, pretežno upokojencev na podedovano ali na lastno parcelo. Največ hiš, med katerimi so prednjačili vikendi, je bilo sicer na tak način zgrajenih v obdobju 1960-1990, vendar je bila največja dinamika suburbanizacije v naslednjem desetletju, ko je bilo v desetih letih (1990-2000) zgrajenih kar 22 \% vseh hiš. Primerno socialnemu položaju večjega dela graditeljev je čas gradnje nadpovprečno dolg, kar na videz sicer kaže na hitrejšo suburbanizacijo, kot je v resnici na to vezana dinamika rasti števila prebivalstva. Kompleksnost suburbanizacijskih procesov v obeh naseljih pa odseva tudi v dvojni strukturi stavb, s stanovanjsko in s prostočasno funkcijo. Znaten delež (nad $10 \%$ ) opuščenih zgradb, razmerja med tipi zgradb ter opazne razlike med obema naseljema Gorco in Slatino zelo nazorno kažejo na razvojne razlike med posameznimi naselji in med posameznimi deli pokrajine. Še posebej pa so razlike med naselji neposredno soodvisne od njihovega socialnoekonomskega razvoja.

V haloških obrobnih in slemenskih naseljih se je v zadnjem obdobju kljub oslabljeni demografski in gospodarski zgradbi bistveno izboljšala infrastrukturna opremljenost. Pozitivne spremembe na področju gradnje in vzdrževanja cest, oskrbe z vodo, ravnanja z odpadki ter telefonskih povezav so rezultat uspešnega dela občin, ki si v prvi vrsti prizadevajo urediti osnovne bivalne potrebe prebivalcev. Zaradi razpršene poselitve in gričevnatega terena ter pogostih neurij je vzdrževanje in urejanje cest drago in zahtevno. Cestno omrežje kaže na kakovost življenjskega okolja, saj zagotavlja osnovne pogoje za gospodarsko in socialno aktivnost prebivalcev, zato $\mathrm{v}$ obeh obravnavanih naseljih postavljajo prebivalci urejanje in vzdrževanje cest med najnujnejše ukrepe. Izboljšana infrastrukturna opremljenost sicer spreminja življenjske pogoje domačinov, vendar bistvenega vpliva na izboljšanje demografske in gospodarske zgradbe doslej ni imela, zaslediti pa tudi ni povečanja gospodarskih naložb in turističnega razvoja.

Največjo težavo predstavlja urejanje kanalizacije zaradi razpršene poselitve ter zahtevne in drage gradnje. Male in predvsem rastlinske čistilne naprave so tehnično ustrezna in cenovno sprejemljiva rešitev, vendar je ključnega pomena osveščanje domačinov, ki morajo sprejeti ekološko ravnanje kot vrednoto za lastno življenje in trajnostni razvoj. Prebivalci obeh naselij izražajo visoko stopnjo zadovoljstva z bivalnimi razmerami, saj jih na Gorci dobrih $83 \%$ ne bi zamenjalo življenjskega okolja, v Slatini pa 77 \%. Mir in neokrnjena narava ter zagotovljeni stanovanjski pogoji ali lastna parcela so vrednote, ki jih prebivalci najpogosteje 
Slika 7: Intenzivnost rabe vinogradniških površin v KO Slatina in KO Gorca

Figure 7: Intensive use of wine growing areas in the Slatina and Gorca cadastral municipalities

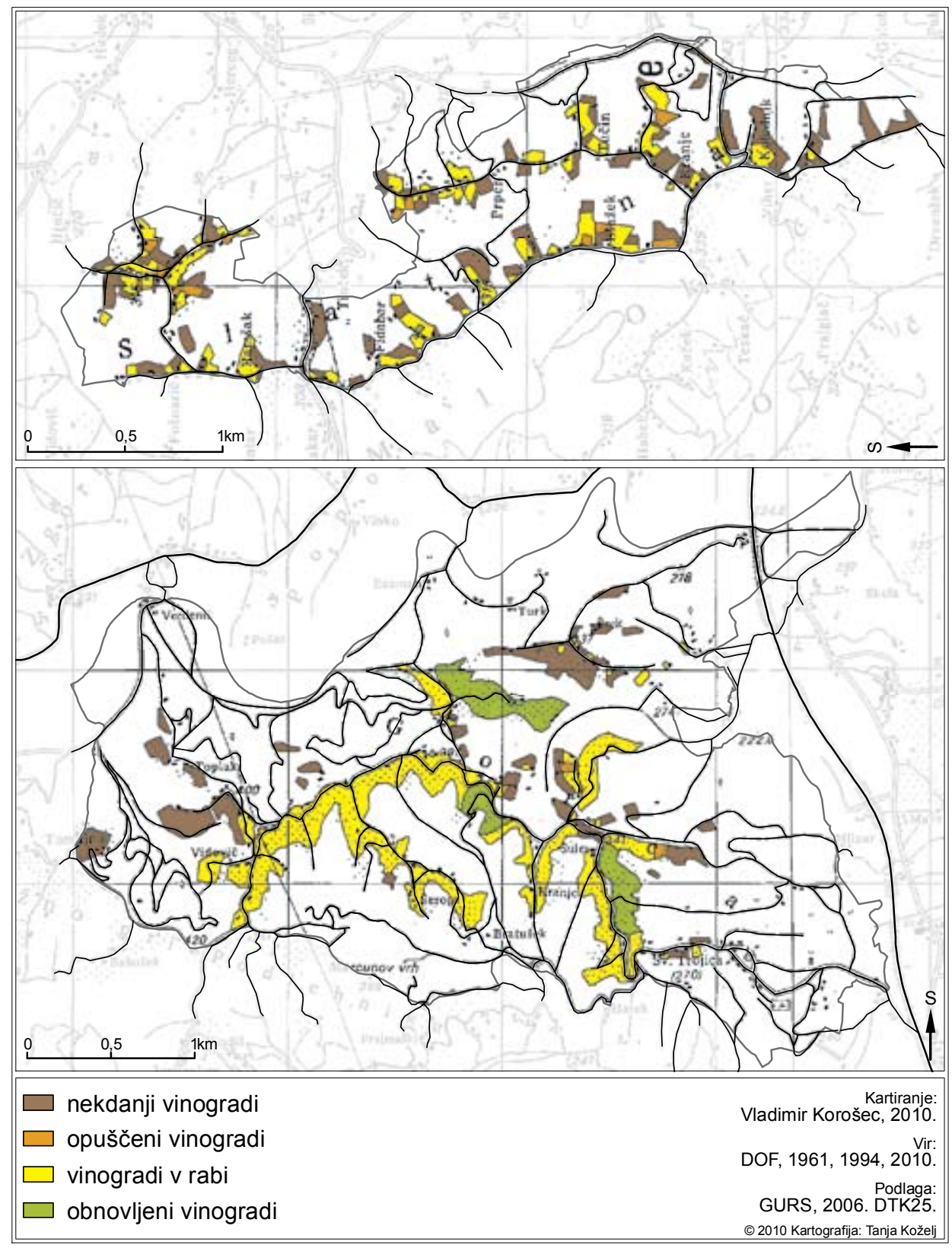


omenjajo kot pomembne prednosti bivanja v obravnavanih naseljih, medtem ko v kmetijski pridelavi, s čimer si družine znižujejo življenjske stroške, ne vidijo posebnih ugodnosti. In to kljub temu, da je v obeh naseljih še vedno dobra tretjina kmečkih gospodinjstev, večina teh pa na manjših površinah prideluje vrtnine le za lastne potrebe. V Halozah se je ohranila tradicionalna razdrobljena zemljiška struktura, ki je značilna za večino slovenskih perifernih območij, za katero Klemenčič celo meni, da datira v 19. st. (2003, 13).

Za haloška periferna naselja ne moremo govoriti o urbanizaciji, ki v svojem bistvu pomeni socialne, gospodarske, funkcijske in morfološke spremembe, temveč zgolj o nehomogeni modernizaciji, za katero je značilno izboljšanje javne infrastrukture, oskrbe in življenjskih razmer gospodinjstev ter boljša prometna povezanost s centralnimi kraji in regionalnimi središči. Ob tem je treba omeniti javni potniški promet, ki se ni prilagodil specifičnim naravnim pogojem in potrebam lokalnega prebivalstva. Ti so skoraj povsem odvisni od osebnih prevoznih sredstev, kar za ostarelo prebivalstvo predstavlja dodatni problem.

V zadnjem obdobju so se izboljšale oskrbne funkcije nekaterih haloških centralnih naselij. Nove trgovine z osnovno oskrbo so v Zavrču, Podlehniku in Majšperku, vendar se te ne morejo primerjati s pestro in raznovrstno ponudbo v bližnjih regionalnih središčih. $\mathrm{Z}$ osnovnimi življenjskimi potrebščinami se na Ptuju redno oskrbuje več kot 50 \% prebivalcev obravnavanih naselij, kar pogosto povezujejo z zaposlitvijo, obiskom zdravnika ali drugimi storitvami. Nedvomno k temu prispeva neustrezna oskrbna mreža na območju Haloz, saj $46 \%$ anketiranih prebivalcev Slatine in $27 \%$ anketiranih prebivalcev Gorce pogreša dobro založeno trgovino v centralnem naselju.

Preglednica 6: Funkcija zgradb v naseljih Slatina in Gorca, 2010

Table 6: The function of buildings in Slatina and Gorca villages, 2010

\begin{tabular}{|l|c|c|c|c|}
\hline \multirow{2}{*}{ Naselje/vrsta zgradbe } & \multicolumn{2}{|c|}{ GORCA } & \multicolumn{2}{c|}{ SLATINA } \\
\cline { 2 - 5 } & Število & $\mathbf{\%}$ & Stevilo & $\mathbf{\%}$ \\
\hline Javne zgradbe & 6 & 5,1 & $/$ & $/$ \\
\hline Vikend & 33 & 27,8 & 44 & 43,1 \\
\hline Stanovanjska hiša & 41 & 34,5 & 40 & 39,2 \\
\hline Nova hiša & 21 & 17,6 & 8 & 7,9 \\
\hline Zapuščen objekt & 18 & 15,0 & 10 & 9,8 \\
\hline Skupaj & $\mathbf{1 1 9}$ & $\mathbf{1 0 0}$ & $\mathbf{1 0 2}$ & $\mathbf{1 0 0}$ \\
\hline
\end{tabular}

Vir/Source: Kartiranje 2010

Naselji Gorca in Slatina se razlikujeta tudi v poselitveni strukturi. V obeh je sicer okrog 50 \% nenaseljenih zgradb, kar je značilnost večine haloških perifernih naselij, ki jih je močno preoblikovala depopulacija (slika 7). Ker v Slatini dobrih $43 \%$ vseh zgradb predstavljajo vikendi, na Gorci pa le 27,8 \% in je večina teh zgradila sedaj že ostarela generacija, emocionalno in funkcionalno vezana na vinograd oziroma pridelavo vina za domače potrebe, se razmerje med stanovanjskimi hišami in vikendi spreminja v prid prvim, žal skupaj z zmanjševanjem in ekstenzifikacijo vinogradniških površin. Za Gorco je hkrati značilna višja stopnja modernizacije, saj je tretjina stalno naseljenih hiš obnovljenih ali novih. Dobršen del naselja Gorca 
je namreč na ravnici ob Rogatnici in Dravinji, kjer so boljši pogoji za bivanje; nasprotno pa je v gričevnatem delu Gorce veliko zapuščenih stavb.

Obe naselji ne spreminjata funkcijske in morfološke zgradbe, saj ohranjata stalno in občasno bivalno funkcijo, razpršeno poselitev različnih socialnih tipov gospodinjstev, zgoščata slemensko poselitev ob osrednji prometnici z ustrezno komunalno infrastrukturo in se ne širita po pobočjih. Gre za ohranjanje tradicionalne poselitvene sestave, ki se bo z opuščanjem vinogradništva v Slatini in njegovim preoblikovanjem na Gorci ter s preoblikovanjem vikendov v prihodnosti zagotovo bistveno spremenila. Proces je nakazan z zgostitvijo ob slemenskih prometnicah, še posebej v Slatini, medtem ko ta proces v naselju Gorca zaostaja. Suburbanizacija je že pred desetletji segla na obrobje večjih dolin in z vikendi tudi na druge razpoložljive lokacije. Okrepila pa se bo v ožjih območjih občinskih središč ter še posebej na obrobju širših privlačnejših in prometno dostopnejših dolin. Urbanizacija je povezana tudi z izredno ugodnimi cenami nekdanjih kmetijskih zemljišč, ki zaradi močne deagrarizacije in zato $\mathrm{z}$ absolutnim pomanjkanjem agrarne delovne sile po vsej verjetnosti za kmetijstvo niso več zanimive. Očitno se Halozam, ali vsaj znatnemu delu haloških naselij, v bodoče obeta krepitev funkcije spalnega naselja.

\section{SKLEP}

Raziskava katastrskih občin Gorca in Slatina je izpostavila temeljno razvojno problematiko Haloz, ene najmanj razvitih slovenskih pokrajin. Vse od konca druge svetovne vojne, torej dobrih 65 let, se Haloze kljub precejšnjim prizadevanjem niso uspele približati razvitejšim regijam. Geografske in druge raziskave opozarjajo celo na njihovo nadaljnje razvojno zaostajanje. Ob tem se glede razvojne problematike nehote poraja primerjava s starim srednjeveškim jedrom Ptuja. In še več, obema grozijo razvojni trendi z določenimi neugodnimi strukturnimi posledicami.

Obravnavani katastrski občini sta kar dober primer kmetijstva v naravno ugodnejših območjih vzhodnih ali vinorodnih Haloz. Pri tem ima Gorca boljše reliefne pogoje in je zaradi tega doživljala intenzivno vinogradništvo. Slatina s slabšimi reliefnimi pogoji in neugodno zemljiško zgradbo pa pomembnejšega kmetijstva ni mogla razviti. Razvojno je danes kmetijstvo v obeh primerih krizno, podobno kot v reliefno izredno dinamičnih Halozah na sploh. Še slabši pogoji za kmetijstvo so v zahodnih višjih gozdnatih Halozah.

Slovenski geografi že od šestdesetih let preteklega stoletja posvečajo regionalno razvojni problematiki veliko pozornost. Domačin in velik ljubitelj Haloz Vladimir Bračič je z doktorsko disertacijo, ki je leta 1967 izšla v knjigi 'Vinorodne Haloze', temeljito predstavil in ovrednotil temeljne razvojne dejavnike, ki so še vedno, morda v nekem drugem družbenoekonomskem okolju, prisotni. Bračič je podobno študijo objavil leta 1982 tudi za zahodni del Haloz v knjigi ‘Gozdnate Haloze'. Obsežen odgovor na regionalno razvojna vprašanja regije predstavlja tudi knjiga ‘Spodnje Podravje s Prlekijo' 1996, kjer so predstavljeni rezultati doslej največjega slovenskega geografskega raziskovalnega projekta. Podoben geografski raziskovalni projekt je Oddelek za geografijo Filozofske fakultete zaključil 2010 leta in ga predstavil v knjigi. V naštetih delih so prikazani razvojni pogoji in možnosti, zato jih na tem mestu ne kaže ponavljati. 
Glede na naravne pogoje, položaj regije in njenega prebivalstvenega potenciala je $\mathrm{v}$ Halozah največ pogojev za kmetijstvo, zlasti njegov nižji vzhodni vinorodni del, za turizem $\mathrm{v}$ povezavi z drugimi regijskimi turističnimi potenciali in za specifično suburbanizacijo, povezano z vikendaštvom. Opozoriti pa je potrebno na najbolj pereče probleme, med katerimi je kar nekaj takšnih, ki vplivajo na razvoj Haloz že desetletja. Med njimi zagotovo najbolj izstopa napredujoče opuščanje kmetijskih površin, v mnogih naseljih tudi vinogradniških, ter zaradi zaraščanja zemljišč spreminjanje videza kulturne krajine.

Že desetletja izpostavljena oddaljenost od regionalnih središč in od delovnih mest se s suburbanizacijo vrednostno spreminja zaradi izboljšane prometne infrastrukture in razmaha motorizacije, kar olajšuje dnevno migracijo. V razvitem svetu je prednost živeti na podeželju in delati v mestu. Na območju Haloz je bivanje v podeželskih naseljih povezano tudi s socialnimi razmerami, saj si posamezne skupine prebivalcev z dedovanjem stanovanj in gradbenih zemljišč ter ugodnimi nakupi stanovanj ter priseljevanjem lažje zagotovijo ustrezne življenjske pogoje.

Reliefno ena najbolj pestrih pokrajin v Sloveniji je tudi vizualno ena najbolj privlačnih za bivanje in turizem, tudi zaradi v zadnjem desetletju vse bolj urejene osnovne infrastrukture.

Kmetijstvo ima v vinogradništvu pogoje za intenzivno tržno pridelavo. Žal je povsem zapostavljeno tradicionalno sadjarstvo, ki bi lahko ob primerni in specializirani pridelavi nudilo ugodne pogoje za razvoj dopolnilnih dejavnosti, kot sta sušenje sadja in žganjekuha. Subpanonska klima pa omogoča še druge vrste kmetijske usmeritve, med katerimi prednjači pridelava vrtnin. Zaradi pomanjkanja ustrezne delovne sile je lahko v bodoče kmetijska raba zemlje vprašljiva.

Turizem v lepem, zdravem in mirnem okolju, povezan s kmetijsko pridelavo, zahteva ustrezno in kvalitetno infrastrukturo, predvsem pa inovativnost, znanje in usposobljenost ponudnikov ter dobro organizirano in ciljno usmerjeno promocijo celotne regije. Dosedanji razvoj te dejavnosti v Halozah kaže na premajhen turistični promet skupaj z ekonomsko in socialno prešibko ptujsko turistično regijo in tudi širšo regijo. Njen sicer izredno ugoden makro položaj na eni od najpomembnejših prometnih točk Srednje Evrope in ne preskromno rečeno tudi vse Evrope, se v ožjem regionalnem okviru ne manifestira. Še bolj kot širše domače vplivno območje SV Slovenije so bližnja tri območja sosednjih držav ekonomsko in socialno šibkejša. Posledice se jasno kažejo tudi v stanju najbolj atraktivnih turističnih točk (Borl, Gorca, Švabovo, Štatenberg) skromno število turističnih kmetij in druge turistične infrastrukture. Tudi številni ustrezno opremljeni vikendi bi bili dobra osnova hitrejšemu razvoju ne le turističnim obiskom, temveč tudi stacionarnemu turizmu. Očitno je za to potrebno znatno razširiti haloško in sploh širšo ptujsko turistično vplivno območje. Turistično je neizkoriščen transevropski prometni koridor proti Balkanu, ki haloškemu in tudi ptujskemu turizmu bistveno bolj škoduje kot prinaša koristi.

Še posebej izstopa vprašanje organizacije kmetijstva, turizma, infrastrukture in drugega v sodelovanju sedmih občin ter njihovega vključevanja v regionalni razvoj. Kot notranje razvojne pole bi bilo potrebno okrepiti haloška lokalna središča, tudi kot močnejša zaposlitvena središča. Izven regije se zaposlitvena središča v času gospodarske krize soočajo z razmeroma neuspešnim proizvodnim in organizacijskim preoblikovanjem, kar ne prispeva $\mathrm{k}$ rasti novih delovnih mest. Veliko možnosti za razvoj kažejo različne storitvene dejavnosti, 
katerih razvoj je odvisen predvsem od sposobnosti lokalnega prebivalstva za uresničevanje podjetniških idej.

Problematična je še vedno prometna infrastruktura. Glavna prometnica proti Hrvaški bi morala dobiti tudi močnejšo turistično funkcijo in možnost prodaje domačih kmetijskih pridelkov.

Temeljni razvojni problem v osnovni gospodarski usmeritvi, ki je še vedno kmetijstvo, in ki seveda izvira iz vsega zgoraj povedanega, pa je pomanjkanje ustrezne delovne sile. Višje kvalificirana delovna sila in priseljenci se niso pripravljeni ukvarjati s kmetijstvom, zato je v kmetijstvu že aktualna cenejša tuja delovna V širokem spektru v Haloze priseljenega prebivalstva prevladujeta dve kategoriji: premožnejši, ki kupujejo večje komplekse poceni zemlje brez resnejših namenov kmetijske obdelave teh površin in manj premožni, vključno z večino vikendašev in številnimi upokojenci, ki na manjših kupljenih ali podedovanih parcelah pridelujejo hrano za svoje potrebe. Pomanjkanje poslovnih pobud na področju kmetijstva z nakupi kmetijskih zemljǐ̌č ter stanovanjskih in poslovnih objektov izkoriščajo pretežno tuji lastniki kapitala, tudi tuji vinogradniki, ki se na dolgi rok zavedajo številnih razvojnih priložnosti v Halozah. Vsi omenjeni kompleksni razvojni procesi bodo v Halozah, ki ležijo v osredju evropskih dogajanj, odločilno vplivali na razvoj regije, v geopolitičnem pogledu pa tudi na strukturo prebivalstva in na lastništvo zemlje.

\section{Viri in literatura}

Bračič, V. 1967: Vinorodne Haloze. Maribor.

Bračič, V. 1982: Gozdnate Haloze. Maribor.

Kladnik, D. 1996: Problematika preobrazbe podeželja z vidika prilagajanja kmetijske pridelave normativom v Evropski zvezi. V: Spodnje Podravje s Prlekijo, str. 297-311. Ljubljana.

Klemenčič, M. M. 2003: Civilizacijske razvojne stopnje in razvojni problemi obrobnih območij v Sloveniji. Dela 19, str. 153-164. Ljubljana.

Klemenčič, M. M. 2005: Nova razvojna strategija pokrajinsko homogenih obrobnih območij Slovenije. Dela 24, str. 185-193. Ljubljana.

Klemenčič, M. M., Lampič, B., Potočnik, I. 2009: Življenjska (ne)moč obrobnih podeželskih območij v Sloveniji. GeograFF 3. Ljubljana.

Klemenčič, V. 1996: Tendence demografske preobrazbe v Spodnjem Podravju in vzhodnih Slovenskih goricah v zadnjih treh desetletjih. V: Spodnje Podravje s Prlekijo, str. 201-211. Ljubljana.

Klemenčič, V. 2003: Procesi deagrarizacije in urbanizacije slovenskega podeželja. Dela 13, str 7-21. Ljubljana.

Klemenčič, V. 2005: Poskus opredelitve sodobnih problemov razvoja kulturne pokrajine slovenskega podeželja. Dela 24, str. 171-184. Ljubljana.

Korošec, V. 2002: Razvojni problemi podeželskih naselij Spodnjega Podravja. Doktorska disertacija. Oddelek za geografijo, Filozofska fakulteta Univerze v Ljubljani. Ljubljana.

Korošec, V. 2005: Socio-ekonomski in funkcijski razvoj naselij na območju Cirkulan. Svet Belanov, str. 33-42. Cirkulane. 
Korošec, V., 2008: Raznolikost razvojnih priložnosti na območju Haloz. Haloze - pokrajina, ljudje in vino, str. 17-49. Ptuj.

Medmrežje 1: http://www.stat.si/pxweb/Dialog/Soveshow.osp (2. 9. 2010).

Petek, F. 2007: Spreminjanje rabe tal v severnih Goriških brdih. Geografski vestnik 79, 1, str. 9-23. Ljubljana.

Potočnik, I. 2002: Iskanje dodatnih virov zaslužka na podeželju: primer dopolnilnih dejavnosti na kmetijah v Sloveniji. Dela 17. Ljubljana.

Ravbar, M. 1996: Urbanizacija Spodnjega Podravja s Prlekijo ter vrednotenje suburbanizacijskih pojavov v obmestju Ptuj. V: Spodnje Podravje s Prlekijo, str. 182-196. Ljubljana.

Ravbar, M., Razpotnik, N. 2008: Geografska analiza razvojnih dejavnikov v Sloveniji: ustvarjalnost in naložbe. Geografski vestnik 80, 2, 81-93. Ljubljana.

SIZAP. 79/GU Ptuj, KO Gorca, škatla številka 5.

SIZAP. 79/GU Ptuj, KO Slatina, škatla številka 6.

Značilnosti regionalnega razvoja in razvojni potenciali Spodnjega Podravja. Aplikativni raziskovalni projekt. Filozofska fakulteta Univerze v Ljubljani in Znanstvenoraziskovalni inštitut Bistra Ptuj. Ljubljana, 2010.

\title{
DEVELOPMENT PROBLEMS OF HALOZE AT THE EXAMPLES OF GORCA AND SLATINA CADASTRAL MUNICIPALITIES
}

\begin{abstract}
Summary
Haloze Tertiary hills in the northeastern Slovenia, located between the river Drava in the north, river Dravinja in the west and the Croatian border in the east, maintains the tradition of an undeveloped agricultural region. The eastern part is oriented into wine-growing while more than $50 \%$ of the higher western part is covered by forests. The extremely unfavourable living conditions forced a significant part of the population to move into neighbouring industrial centres and thus contributing to the poor demographic potential which, besides other factors (infertile land, dynamic of the relief and unfavourable land holding structure, etc.) hinders any significant development. Therefore, wine-growing faced with deterioration which was the most contributed by denationalization. Active population commutes to work into the neighbouring centres.

To get an in-depth insight in development processes and possibilities, we undertook a case study of two cadastral municipalities. In the Gorca cadastral municipality where the relief is less steep, vineyards were grown on terraces on which high-quality grapes were cultivated by the Agricultural Combine Ptuj. In the 1990's, the land owned by the combine was available for lease to its former employees and others. This was the start of deterioration of the leased wineyards since they were only the subject of exploitation and no upkeeping. The situation was the same with bigger leaseholders from other regions. The area under vines in the entire Haloze and in the Gorca cadastral community is thus decreasing. The workforce has grown old since young people show no interest in such kind of work. The value of the
\end{abstract}


land decreased significantly what attracted foreigners to buy big and quality wine-growing surfaces and hire cheap foreign workforce to carry out the recovery of vineyards.

The Slatina cadastral municipality was not suitable for intensive wine-growing due to its abundant ridges and steep slopes. Dispersed land holding structure also prevents agricultural commercialization. Unfavourable natural conditions forced the inhabitants to move or commute to neighbouring centres. In the recent years, ridges have been the places of significant urbanization, while former weekend-houses are being turned into permanent homes.

Both cadastral municipalities are typical examples of developmental lagging behind as a result of numerous factors - natural and socio-economic. Economic potential of the region is extremely poor. The long-standing developmental lagging behind has created an unfavourable demographic structure. Thus, several attempts for the development of tourism in this natural attractive region have failed, by pointing out revival of the most attractive tourist objects: Borl castle and villa Gorca. 